\title{
Correlation Between Children's Temperament and Risk Factor of Attention Deficit/Hyperactivity Disodrer in Elementary School
}

\author{
Cheifia Krissanti Sasono $^{1}$, Irwanto², Yunias Setiawati ${ }^{*}$ \\ ${ }^{1}$ Faculty of Medicine, Universitas Airlangga, Surabaya, Indonesia \\ ${ }^{2}$ Department of Pediatric, Faculty of Medicine, Universitas Airlangga, Surabaya, Indonesia - Dr. Soetomo General Hospital \\ Surabaya, Indonesia \\ ${ }^{3}$ Department of Psychiatry, Faculty of Medicine, Universitas Airlangga, Surabaya, Indonesia - Dr. Soetomo General Hospital \\ Surabaya, Indonesia
}

\section{A R T I C L E I N F O}

\section{Article history:}

Received 12 April 2019

Received in revised form 24 May

2019

Accepted 10 June 2019

Available online 30 June 2019

\section{Keywords:}

Attention-Deficit/Hyperactivity

Disorder,

Temperament,

Abbreviated Conners' Rating Scale, Temperament in Middle Childhood Questionnaire,

Elementary school.

*) Corresponding author:

yunias.setiawati@gmail.com

\begin{abstract}
A B S T R A C T
Introduction: The main symptoms of Attention-Deficit/Hyperactivity Disorder (ADHD) are hyperactivity, impulsivity, and inattention. While temperament in children with ADHD is described as high in negative reactivity, low task persistence, high activity, low attentional focusing, high impulsivity and low inhibitory control. This study aims to analyze the correlation between children's temperament and risk factor of ADHD.

Methods: This study used cross-sectional design with Abbreviated Conners' Rating Scale and Temperament in Middle Childhood questionnaire for instrument. All data are analyzed using Pearson correlation.

Results: Prevalence of children with risks of ADHD from total subject was 21/114 students (18,4\%, consisted of 18 males ( $81 \%$ ) and 3 females (19\%) with average age was 10 years old. The majority of participants were in the sixth grade $(28.6 \%)$. There was a positive and weak correlation between surgency and ADHD symptoms $(3,05 \pm 0,75, \mathrm{p}=0,045 ; \mathrm{r}=0,44)$.

Conclusion: There was no significant correlation between the negative affect and effortful control dimensions of temperament with severity of ADHD, however this study found a positive and weak correlation between surgency and risk factor of ADHD.
\end{abstract}

\section{Introduction}

Attention-Deficit/Hyperactivity Disorder (ADHD) is a common neurobiological disorder in children at the age of elementary school. The main symptoms are hyperactivity, inattention, and impulsivity. ${ }^{1}$ However, people are not aware of this disorder and assume that those symptoms are just common behaviors of children in their age. If left untreated, children with ADHD will have social, educational or work problems in society caused by the severity of the symptoms. ${ }^{2}$ According to Diagnostic and Statistical Manual (DSM V), prevalence of ADHD in children aged 12 years old is 3-7\% around the world. In Indonesia, there is no consistent data of ADHD prevalence amongst children. ${ }^{1}$ But, according to Statistics Indonesia, there were approximately 8.3 million from 82 million children suffered from ADHD in 2007 and most of them were children with special needs. ${ }^{13}$

Temperament is a style of behavior that can be seen consistently in individual response or reaction towards environment. ${ }^{3}$ Everyone has different temperament based on their genetical and biological developments. Rothbart divided temperament into 3 dimensions: surgency, negative affect, and effortful control. ${ }^{4}$ Every dimension has their own scales which is seen in Temperament in Middle Childhood Questionnaire (TMCQ). ${ }^{5}$ The various types of temperament in children usually are misunderstood as symptoms of ADHD, because every individual has different self-regulation. Temperament of children with ADHD is described as high in negative reactivity, low task persistence, high activity, low attentional focusing, high impulsivity and low inhibitory control according to McClowry theory of temperament. ${ }^{6}$ Therefore, the purpose of this study is to analyze the correlation between children's temperament and risk factors of ADHD since in Indonesia there is not many research conducted.

\footnotetext{
Methods

This study used cross-sectional method and conducted at Bina Karya Elementary School from April to October 2018. Data from subjects including age, gender, ADHD risk factor, and temperament. Parents/caretaker were given
} 
Abbreviated Conners' Rating Scale according to the manual book of "Stimulasi, Deteksi, dan Intervensi Dini Tumbuh Kembang Anak 2016 (SDIDTK)" to determine ADHD risk factors in children and also Temperament in Middle Childhood Questionnaire (TMCQ) for temperament assessment tool that observes 3 variables, namely surgency, negative affect, and effortful control. Surgency consists of activity level, high intensity pleasure, impulsivity, shyness (reversed), and assertiveness. Scales to determine effortful control are attention, inhibitory control, activation control, low intensity pleasure, and perceptual sensitivity. Negative affect consists of anger/frustration, discomfort, fear, sadness, and soothability (reversed). From total 390 students in Bina Karya Elementary School, 114 students willing to be included in the study. Students were screened using inclusion criteria which is no other mental illness suffered by the student. The samples then were analyzed with Pearson Correlation $(\alpha=0.05)$ using SPSS Statistics to determine correlation. This study had been approved by the ethical committees from Faculty of Medicine, Universitas Airlangga (316/EC/KEPK/FKUA/2018).

\section{Results}

From 114 students, there were 22 children with risk factor of ADHD (19.3\%) and only 21 students who met the inclusion criteria as shown in table 1 . One student had another mental illness and was not included as subject. ACRS score above 13was defined as having risk of ADHD.

Table 1. Prevalence of ADHD in Bina Karya Elementary School using Abbreviated Conners' Rating Scale Gestation and Birth History

\begin{tabular}{ccc}
\hline ACRS score & Total $(\mathbf{n}=\mathbf{1 1 4})$ & Percentage $(\mathbf{\%})$ \\
\hline$<13$ & 92 & 80,7 \\
$\geq 13$ & 22 & 19,3 \\
\hline
\end{tabular}

From 21 respondents, there were 18 boys (81\%) and 4 girls $(19 \%)$ assessed in this research and majority were in their sixth grade $(28.6 \%)$ with average age was 10 .

Table 2. Profile of children with risk factor of ADHD

\begin{tabular}{|c|c|c|}
\hline Variable & Total $(n=21)$ & Percentage (\%) \\
\hline \multicolumn{3}{|l|}{ Gender } \\
\hline Male & 17 & 81 \\
\hline Female & 4 & 19 \\
\hline \multicolumn{3}{|l|}{ Age } \\
\hline 6 & 3 & 14.3 \\
\hline 7 & 1 & 4.8 \\
\hline 8 & 3 & 14.3 \\
\hline 10 & 2 & 9.5 \\
\hline 11 & 3 & 14.3 \\
\hline 12 & 4 & 19 \\
\hline 13 & 5 & 23.8 \\
\hline
\end{tabular}

\section{Abbreviated Conners' Rating Scale (ACRS)}

Mean of the ACRS score for parents/caretakers was 15.19 with $\mathrm{SD} \pm 2,620$. It can be seen in table 3 that the scores with the highest percentage $(23.8 \%)$ are 13 ,
14, and 15. These results were still under the mean score, which showed that majority of children in the elementary still had low symptoms of ADHD.

Table 3. Distribution frequency of ACRS score

\begin{tabular}{ccc}
\hline ACRS Score & Total $\mathbf{( n = 2 1 )}$ & Percentage $\mathbf{( \% )}$ \\
\hline 13 & 5 & 23,8 \\
14 & 5 & 23,8 \\
15 & 5 & 23.8 \\
16 & 3 & 4.8 \\
17 & 1 & 4,8 \\
20 & 1 & 4.8 \\
\hline
\end{tabular}

Table 4. Children's temperament assessment using Temperament in Middle Childhood Questionnaire

\begin{tabular}{|c|c|c|c|c|}
\hline Scale & Minimum & Maximum & $\begin{array}{l}\text { Mean } \\
(\mathrm{SD}) \\
\mathrm{n}=21\end{array}$ & Median \\
\hline $\begin{array}{l}\text { Activation } \\
\text { Control }\end{array}$ & 2.27 & 4.80 & $\begin{array}{c}3.16 \\
(0.57)\end{array}$ & 3.26 \\
\hline Activity Level & 3.11 & 5.00 & $\begin{array}{c}4.08 \\
(0.56)\end{array}$ & 4.22 \\
\hline Affiliation & 2.00 & 4.90 & $\begin{array}{c}3.62 \\
(0.77)\end{array}$ & 3.7 \\
\hline $\begin{array}{l}\text { Anger/ } \\
\text { Frustration }\end{array}$ & 1.00 & 5.00 & $\begin{array}{c}3.31 \\
(1.04) \\
\end{array}$ & 3.43 \\
\hline $\begin{array}{l}\text { Assertiveness/ } \\
\text { Dominance }\end{array}$ & 1.50 & 4.63 & $\begin{array}{c}3.31 \\
(0.92) \\
\end{array}$ & 2.88 \\
\hline $\begin{array}{l}\text { Attention } \\
\text { Focusing }\end{array}$ & 1.38 & 3.00 & $\begin{array}{c}2.14 \\
(0.58) \\
\end{array}$ & 2.12 \\
\hline Discomfort & 1.00 & 4.90 & $\begin{array}{c}2.38 \\
(1.04)\end{array}$ & 2.5 \\
\hline $\begin{array}{l}\text { Fantasy/ } \\
\text { Openness }\end{array}$ & 1.78 & 4.56 & $\begin{array}{l}2.98 \\
(0.7)\end{array}$ & 2.89 \\
\hline Fear & 1.00 & 4.11 & $\begin{array}{c}2.26 \\
(0.73) \\
\end{array}$ & 2.22 \\
\hline $\begin{array}{l}\text { High Intensity } \\
\text { Pleasure }\end{array}$ & 2.55 & 4.82 & $\begin{array}{c}3.83 \\
(0.51) \\
\end{array}$ & 3.82 \\
\hline Impulsivity & 1.92 & 4.31 & $\begin{array}{c}3.13 \\
(0.71)\end{array}$ & 3.38 \\
\hline $\begin{array}{l}\text { Inhibitory } \\
\text { Control }\end{array}$ & 2.00 & 4.25 & $\begin{array}{c}3.03 \\
(0.61) \\
\end{array}$ & 3.12 \\
\hline $\begin{array}{l}\text { Low Intensity } \\
\text { Pleasure }\end{array}$ & 1.75 & 4.25 & $\begin{array}{l}2.68 \\
(0.7)\end{array}$ & 2.75 \\
\hline $\begin{array}{l}\text { Perceptual } \\
\text { Sensitivity }\end{array}$ & 1.90 & 4.80 & $\begin{array}{c}3.35 \\
(0.92)\end{array}$ & 3.3 \\
\hline Sadness & 1.60 & 4.80 & $\begin{array}{c}2.85 \\
(0.84)\end{array}$ & 2.7 \\
\hline Shyness & 1.00 & 4.60 & $\begin{array}{l}2.43 \\
(0.8) \\
\end{array}$ & 2.4 \\
\hline Soothability & 1.75 & 4.50 & $\begin{array}{c}3.3 \\
(0.84)\end{array}$ & 3.37 \\
\hline
\end{tabular}




\section{Temperament in Middle Childhood Questionnaire (TMCQ)}

From TMCQ, it was found that most of the students with risk factor of ADHD were high in assertiveness/dominance and fantasy/openness rated by the mean and median. However, they were low in activation control, activity level, discomfort, and impulsivity. (Table 4)

\section{Risk Factor of ADHD and Temperament}

From table 5, there was no significant correlation between the negative affect and effortful control dimensions of temperament with risk factor of ADHD $(p>0,05)$. However, a positive and weak correlation was found between surgency and ADHD symptoms $(p=0,045 ; r=0,44)$. Using independent sample $\mathrm{T}$ test, we found a correlation between surgency and assertiveness/dominance with $\mathrm{p}=0.021$. (Table 5)

Table 5. Correlation between risk factor of ADHD and children's temperament

\begin{tabular}{llc}
\hline \multirow{2}{*}{ Variable } & \multicolumn{2}{c}{ Risk Factor of ADHD } \\
\cline { 2 - 3 } & $\mathbf{R}$ & $\mathbf{P}$ \\
\hline Surgency & 0.44 & 0.045 \\
Effortful Control & 0.22 & 0.341 \\
Negative Effect & 0,36 & 0.103 \\
\hline
\end{tabular}

\section{Discussion}

Majority of children with risk factors of ADHD in this study was male (18\%). This is in accordance with DSM $\mathrm{V}$ (2013) that stated ratio of male and female diagnosed with ADHD is 2:1. ${ }^{1}$ Studies showed similar results about gender majority in children with ADHD since male tends to have high activity level, activation control, fantasy with low attention rather than female. ${ }^{7,8}$

Similar result of normal birth weight domination was founThis study found that there is a weak correlation between children's temperament and risk factors of ADHD. The correlation was found in surgency/extraversion among the 3 dimensions of temperament according to Rothbart. Rothbart stated that surgency is a dimension of temperament that expressed positive emotion, high activity, and dominancy. ${ }^{4}$ Surgency is described as a child with high intensity of pleasure, friendliness, and liveliness. Extraversion is portrayed in the same dimension to show the child's ability to be open in expressing their emotion. This study found that there is a correlation between assertiveness/dominance and risk factor of ADHD with $p=0.21(p<0.05)$. It is in accordance with Karalunas et al. (2014) that divided children with ADHD into 3 categories: mild, surgent, and irritable. Children in the surgent category have high impulsivity, show high dominancy in social life, love extreme or intense activity, and not shy. ${ }^{3,9}$ Wichstrøm et al. (2018) also found that children with high severity of ADHD are low in effortful control but high in surgency and negative affect. ${ }^{10}$ They showed that high negative affect increased the risk of ADHD even though in this study there was no significant correlation between risk factor and negative affect. Emotions included in the domain of negative affect such as anger, sadness, and anxiousness were shown in children's disruptive behavior. Low effortful control also worsens children's ability of limiting themselves. Therefore, it is making parents and caretakers difficult to teach and correct their behavior resulting to wrong parenting that causes high risk of ADHD. It is stated that there are direct and indirect effects of maternal and paternal involvement, poor supervision, and inconsistent discipline on inattention and hyperactivity-impulsivity through child temperament and personality traits. Inconsistent discipline exerted indirect effects on both ADHD symptom dimensions through child conscientiousness, such that higher levels of inconsistency predicted lower levels of conscientiousness, which predicted greater risk of ADHD symptoms. Poor supervision also exerted indirect effects on inattention in child conscientiousness as well as significant indirect effects on hyperactivity-impulsivity in its impact on both child reactive control and conscientiousness. ${ }^{11}$ The small number of samples and subjectivity of the answers in the questionnaires influenced the result of this study. Therefore, further research with larger number of samples is needed to gain a better insight of the correlation between temperament and risk factor of ADHD.

\section{Conclusion}

Students diagnosed with ADHD were dominated by male students. Mostly, age assessed in the study is 13 years old. This study found a positive and weak correlation between surgency and risk factor of ADHDResults from this study showed that elementary school-aged children might have the tendency to turn into ADHD if their behavior and traits are not controlled by parents and caretakers including school teacher. Children might have high activity and dominance during elementary school due to their environment in which they grow and they need parenting to grow effortful control dimension in their temperament. High dominance, activity, impulsivity and low attention might be reasonable in their age and not always refer to ADHD. Therefore, to diagnose a child with ADHD needs professional psychiatrist.

\section{Conflict of Interest}

The author stated there is no conflict of interest

\section{References}

1. American Psychiatric Association. Diagnostic and Statistical Manual of Mental Disorders. Arlington. 2013. 991 p.

2. Matthews M, Nigg JT, Fair DA. The Role of Diffusion Tensor Imaging in the Study of Cognitive Aging. Brain Imaging Behav Neurosci. 2012;(November 2011):289-320.

3. De Pauw SSW, Mervielde I. The Role of Temperament and Personality in Problem Behaviors of Children with ADHD. J Abnorm Child Psychol. 2011;39(2):277-91.

4. Rothbart MK. 1981 Measrmnt of Temp in Infancy.pdf. Vol. 52, Child Development. 1981. p. 569-78.

5. Nystrom B, Bengtsson H. A Psychometric Evaluation of the Temperament in Middle Childhood Questionnaire (TMCQ) in a Swedish sample. Scand J Psychol. 2017;58(6):477-84.

6. Foley M, McClowry SG, Castellanos FX. The Relationship Between Attention Deficit Hyperactivity Disorder and Child Temperament. J Appl Dev Psychol. 2008;29(2):157-69.

7. Hasson R, Fine JG. Gender Differences Among Children with ADHD on Continuous Performance Tests: A Meta Analytic Review. J Atten Disord. 2012;16(3):190-8.

8. Ramtekkar UP, Reiersen AM, Todorov AA, Todd RD. Sex and Age Differences in Attention-Deficit/Hyperactivity Disorder Symptoms and Diagnoses: Implications for DSM-V and ICD-11. J Am Acad Child Adolesc Psychiatry. 2010;49(3):217-28. 
9. Karalunas SL, Fair D, Musser ED, Aykes K, Iyer SP, Nigg JT. Subtyping Attention Deficit/Hyperactivity Disorder Using Temperament Dimensions: Toward Biologically Based Nosologic Criteria. JAMA Psychiatry. 2014;71(9):1015-24.

10. Wichstrøm L, Penelo E, Rensvik Viddal K, de la Osa N, Ezpeleta L. Explaining the Relationship Between Temperament and Symptoms of Psychiatric Disorders from Preschool to Middle Childhood: Hybrid Fixed and Random Effects Models of Norwegian and Spanish children. J Child Psychol Psychiatry Allied Discip. 2018;59(3):28595 .
11. Ullsperger JM, Nikolas MA. Between Parenting Practices and Child Attention Deficit /. 2016;44(1):167-78.

12. Departemen Kesehatan RI. Pedoman Pelaksanaan Stimulasi, Deteksi, dan Intervensi Dini Tumbuh Kembang Anak. Jakarta: Depkes RI. 2016

13. Kemenkes RI. 2010. Survei Demografi dan Kesehatan Indonesia. Jakarta: Kemenkes RI. 